\title{
Ciencia del agua y ética por la vida: pilares de desarrollo equitativo y sustentable
}

El futuro estará cimentado en principios de equidad, responsabilidad, distribución sostenible del espacio y los recursos, $y$ en el respeto de unos por otros de los que vivimos hoy y por quienes

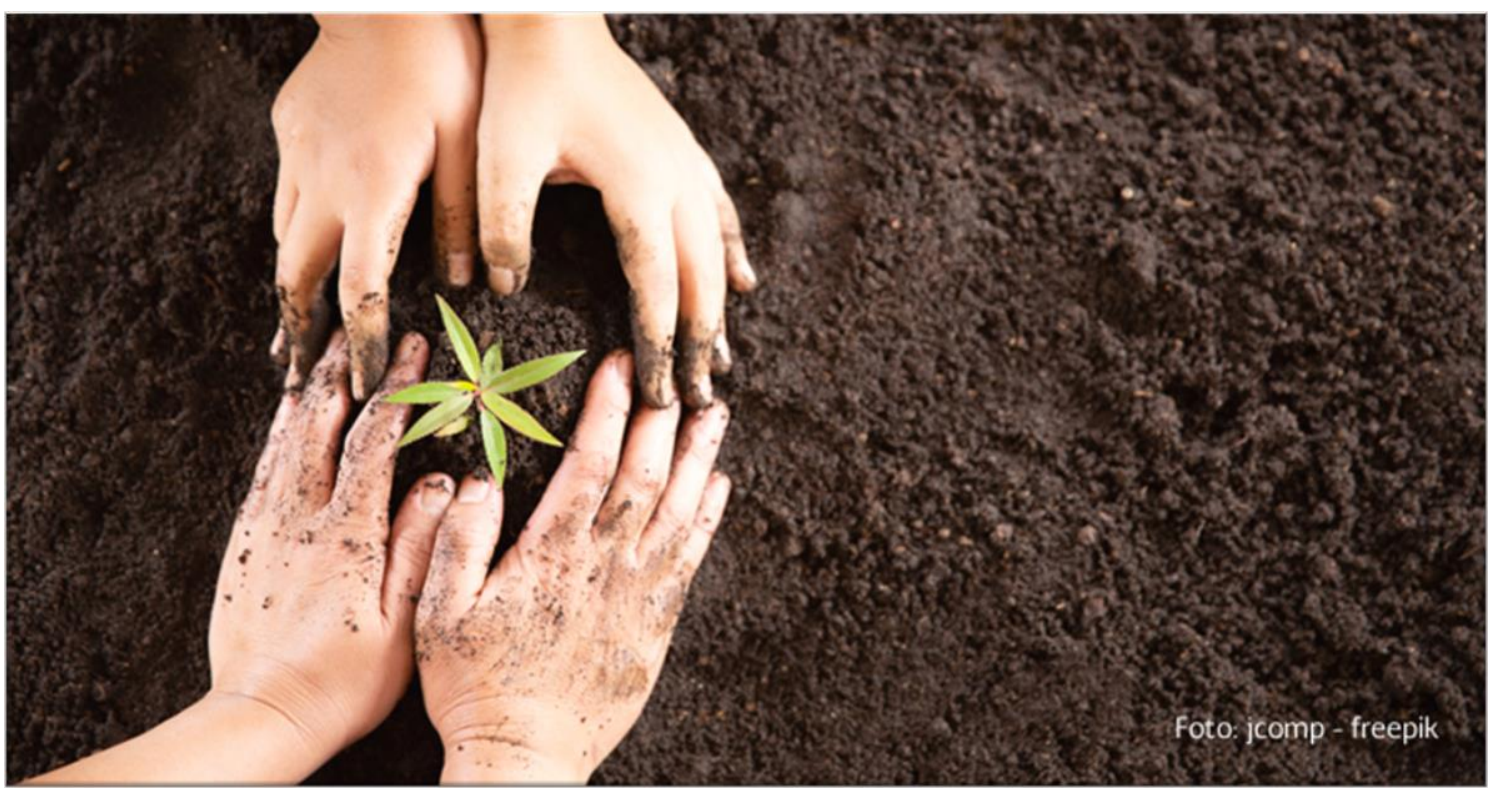

Nos encontramos ante una disyuntiva crítica que como sociedad necesitamos resolver.

Algunos pensadores señalan que es necesario repensar cómo accedemos al progreso, pues los cambios repentinos detonados por el acelerado desarrollo económico global han impuesto una fuerte presión sobre nuestro planeta, lo cual ha resultado en desequilibrios del ciclo hidrológico global, que hoy se manifiestan en eventos extremos, como sequías e inundaciones, pero más importante es la propagación espacial de un virus que pone en riesgo el aseguramiento de la salud y prosperidad de todas las naciones.

Actualmente, la pandemia de COVID-19 es una llamada de atención planetaria que nos señala que cuando parecía estar todo bien por el desarrollo económico del mundo, en realidad no lo estaba. Este virus es una manifestación natural que -además de someter a prueba la capacidad de organización y fraternidad de todas las familias, sociedades, instituciones y gobiernos del planeta- pone en pausa el crecimiento económico de todas las naciones. La lección es simple: el planeta nos dice, a través de un virus con propagación global, que nuestra salud personal sí se relaciona y afecta con la salud del planeta, y que con la degradación ecológica se entrelazan la salud humana y el crecimiento económico global. 
PERSPECTIVAS IMTA (0)

$N^{\circ} .31,2020$

MEDIO AMBIENTE

Autor: Adrián Pedrozo Acuña

DOI: doi.org/10.24850/b-imta-perspectivas-2020-31

En el IMTA estamos ciertos de que es necesario y posible producir desarrollo y movernos hacia un mundo sin pobreza e injusticia de la mano del agua, pero, a la vez, debemos respetar los límites de la sustentabilidad. De esta forma, se detona una transición hídrica que tiene su base en la ética por la vida y que busca asegurar la prosperidad de largo plazo para todos. Nuestra misión, como especialistas del agua, consiste en mantener la habilidad de todos los ecosistemas para dar soporte al mundo moderno y su desarrollo. Esto requiere una transformación total en economías, sociedades, culturas y patrones de consumo y producción. El futuro estará cimentado en principios de equidad, responsabilidad, distribución sostenible del espacio y los recursos, y en el respeto de unos por otros de los que vivimos hoy y por quienes vivirán mañana.

La pandemia ha hecho evidente la visión incompleta que tenemos del agua. En todos los países, su administración ha estado fundada en una perspectiva técnica de eficiencia económica y productividad, soslayando equidad, justicia y participación ciudadana.

Las condiciones actuales nos obligan a voltear a lo local y al cuidado de nuestra salud, de nuestro campo y del agua con una visión de atención comunitaria, solidaria y empática, capaz de reconocer que el bienestar de todos es una obligación ética y moral. El mundo que nacerá deberá reconocer que la mejor decisión ya no es necesariamente la más eficiente desde una perspectiva exclusivamente económica. Las decisiones deberán ser resultado de un análisis con base en evidenca científica, considerando siempre una lente de ética en lo local. Por si este razonamiento fuera poco, el número y nivel de conflictos hídricos que se aprecian en el mundo nos indican que es importante agregar a los conceptos de eficiencia y sustentabilidad hídrica consideraciones relativas a la justicia en la distribución del vital líquido.

Además de los sectores de abasto y producción de alimentos, necesitamos pensar en fomentar un mejor uso del agua por parte de la industria. Por ejemplo, promoviendo prácticas hacia un reciclado completo de agua (huella hídrica cero). Tecnológicamente, no existen obstáculos para movernos hacia ello en todas las industrias. Es posible un desarrollo económico impulsado por una agricultura e industria que utilicen el agua de forma responsable, pero necesitamos reconocer que, para ello, uno de los grandes retos consiste en mover la voluntad y el dinero de aquellos grandes usuarios para dirigirse hacia una mayor eficiencia y una huella hídrica cero. Por un lado, esto depende, de un marco jurídico y de normas que lo fomenten, y podemos ir diseñándolo de forma participativa de la mano del mejor conocimiento disponible. Por otro lado, debemos también reconocer dos cosas: 1, que el modelo de producción extractivo no es sustentable y está agotado y 2 , que requerimos de la ética tanto en el servicio público como en el quehacer agrícola e industrial, de tal suerte que hacer lo correcto por el bien de todos se convierta en un impulso que motive nuestras acciones. Esto nos permitirá caminar como sociedad hacia un desarrollo económico equitativo, soportado por un uso sustentable e inteligente del agua.

Adicionalmente, debemos reconocer que existen límites al mejoramiento de la eficiencia en el uso del agua por parte de los agricultores, en virtud de la trampa que representa la tentación de utilizar el agua ahorrada para producir más (beneficio económico), lo que resulta en un mayor estrés hídrico para las fuentes de abastecimiento.

Para la mayoría de los países, el reto es tripartita: mejorar la productividad hídrica en la agricultura, asegurar que la industria utilice las mejores prácticas y tecnología para el uso del agua y mover a su población hacia dietas con un bajo consumo de carne. 
PERSPECTIVAS IMTA (0)

$\mathrm{N}^{\circ} .31,2020$

Autor: Adrián Pedrozo Acuña

DOI: doi.org/10.24850/b-imta-perspectivas-2020-31

La humanidad ha demostrado capacidad transformativa a lo largo de su historia. Toca el turno al sector hídrico global de hacer del agua el elemento clave que dé soporte a nuestra vida. Al final de cuentas, lo que tenemos que entender es que todos compartimos el mismo planeta, con agua insuficiente para continuar con este modelo económico, que fomenta prácticas de consumo y producción no sustentables. Es por ello que requerimos de la participación de la ciencia y la tecnología del agua en la creación de marcos de trabajo que hagan un uso más sustentable del agua, para así garantizar la salud ambiental del planeta, nuestra propia salud y el futuro de las nuevas generaciones. 